\title{
Effects of Wildfire and the Presence of the Invasive Paulownia tomentosa on the Regeneration of Native Tree Species in North-Central Appalachia
}

\author{
Roger Williams $1, * \mathbb{1}$ and Haibin Wang ${ }^{2}$ \\ 1 School of Environment and Natural Resources, The Ohio State University, Columbus, OH 43210, USA \\ 2 Institute of Engineering and Technology, Northeast Forestry University, Harbin 150040, China; \\ whb_nefu@nefu.edu.cn \\ * Correspondence: williams.1577@osu.edu; Tel.: +1-614-688-4061
}

check for updates

Citation: Williams, R.; Wang, H. Effects of Wildfire and the Presence of the Invasive Paulownia tomentosa on the Regeneration of Native Tree Species in North-Central Appalachia. Fire 2021, 4, 60. https://doi.org/ $10.3390 /$ fire 4030060

Academic Editor: Eva K. Strand

Received: 16 July 2021

Accepted: 2 September 2021

Published: 6 September 2021

Publisher's Note: MDPI stays neutral with regard to jurisdictional claims in published maps and institutional affiliations.

Copyright: (c) 2021 by the authors. Licensee MDPI, Basel, Switzerland. This article is an open access article distributed under the terms and conditions of the Creative Commons Attribution (CC BY) license (https:// creativecommons.org/licenses/by/ $4.0 /)$.

\begin{abstract}
A wildfire occurred in Shawnee State Forest located in southern Ohio that consumed 1215 hectares. Based on earlier forest inventories it was known that paulownia (Paulownia tomentosa), a non-native invasive tree species, occurred in the forest. The objective of this study was to determine if paulownia heavily colonized areas two years after the fire where the burn occurred, and if its presence had a negative impact on the regeneration $(<137 \mathrm{~cm}$ height) of native species-red and white oaks (Quercus sp.), red maple (Acer rubrum), and yellow-poplar (Liriodendron tulipifera). Two years after the fire, paulownia had invaded the burned areas but not at significantly higher densities than occurred in the unburned areas. Fire significantly reduced the number of regenerating stems of white oak and red maple two years after the fire, whereas the number of regenerating stems of red oak increased slightly and that of yellow-poplar increased significantly. In areas where paulownia occurred that experienced wildfire, all species studied displayed a reduction in the number of regenerating stems compared to paulownia's absence in the burn areas. Where paulownia occurred in areas not affected by the wildfire, all the native species studied displayed a reduction in the number of regenerating stems. The average heights of red oak, white oak, and red maple were significantly taller when growing in areas affected by the wildfire due to a more open canopy. However, there was no significant change in the average heights of yellow-poplar. The presence of paulownia in both the burned and unburned areas reduced the number of regenerating stems of the native species studied.
\end{abstract}

Keywords: Paulownia tomentosa; wildfire; red oak; white oak; red maple; yellow-poplar; invasive species; paulownia

\section{Introduction}

In the field of invasion ecology, invasive plants are the most numerous and important species in terms of their negative impact on native species, and thereby pose the greatest concerns [1]. Invasive plants are considered a major threat to ecosystem health and biodiversity because they have not evolved within native ecosystems [2,3]. Invasive plants can alter ecosystems by competing with native plants, causing native plants to be eventually excluded from their ecosystems $[4,5]$. When invasive plant communities become dominant within an ecosystem, the cycling of chemical elements and compounds between the living and nonliving parts of an ecosystem is altered and habitat quality suffers [6,7]. Although few invasive plant species may have a negative impact within their introduced ecosystems [8], those that do have the potential to cause considerable damage to the agriculture and forestry sectors [9].

The establishment of invasive species in forests is strongly promoted by disturbances that create openings in forests [10]. One such invasive species that takes advantages of these disturbances is paulownia (Paulownia tomentosa (Thunb.) Steud.), a deciduous tree native to Eastern Asia, which was introduced initially to the eastern United States in the 
1840s [11,12]. Paulownia has the botanical and silvical characteristics commonly associated with an invasive species that enable it to establish and spread in disturbed areas [13-16]. It is a prolific seed producer, with estimates of 2000 tiny seeds per fruit capsule and tens of millions of seeds produced per individual mature tree in one season [11,17-19]. Winged seeds, each weighing less than a milligram, are wind dispersed, and can travel several kilometers from a parent tree $[17,20,21]$. Paulownia is an extremely fast grower, as young stems are able to grow one meter or more per year [20,22]. Paulownia has the ability to resprout from adventitious buds on the trunk and roots after top-kill from fire, cutting, or other non-fatal damage [20]. These characteristics-small, lightweight winddispersed seeds, a short time (one growing season) between large seed crops, fast growth, short juvenile period, vegetative reproduction capabilities, and perfect flowers-enable paulownia to be an invasive species. Others cite paulownia's ability to germinate and establish in areas where there was no previous population and its ability to colonize large areas as reasons for its invasiveness [21,23]. Fire often acts as a large-scale disturbance that promotes recruitment of some invasive plants [23-25], and fire appears to promote invasions of paulownia [26]. Paulownia was found to invade two separate areas that experienced wildfire in the Linville Gorge Wilderness Area, North Carolina, and the native plant communities changed as a result of its invasion [27].

In the spring of 2009, a human-caused wildfire occurred in Shawnee State Forest located in southern Ohio that burned approximately 1215 hectares. Historically, fires frequented forests in this region once every $5-15$ years and were of mixed severity prior to the establishment of organized fire suppression in 1923 [28]. More recently, this region has experienced an average of 416 fires that burned a total of 942 hectares annually over the past two decades [29], and more than $99 \%$ of these fires are human caused. The Shawnee State fire was of an atypical size because the average size of fires within this region is approximately 2.5 hectares.

The fire intensity was variable across the landscape, and salvage logging operations were performed in areas that experienced high fire intensity where it was anticipated that $100 \%$ mortality of overstory trees would occur as a result. Based on previous forest inventories, it was known that mature (seed-bearing) paulownia trees existed in the forest and that paulownia had become established in the burn areas [30]. However, it was unknown whether paulownia's presence was having a negative impact on the germination and growth of native tree species. Therefore, the objective of this study was to determine the effects of wildfire and the presence of paulownia on the young regeneration $(<137 \mathrm{~cm}$ height) of selected native tree species.

\section{Materials and Methods}

\subsection{Study Site and Field Methods}

Data was collected during the summer of 2011 in Shawnee State Forest (N $38^{\circ} 43^{\prime}$ latitude, $\mathrm{W} 83^{\circ} 14^{\prime}$ longitude) in southern Ohio, which was slightly more than two years after the wildfire of April 2009. Shawnee State Forest comprises over 25,000 ha and is characterized by a highly dissected topography composed of narrow ridges, steep hillsides, and valleys with slopes between 40 and $70 \%$. Soils are primarily of the Shelocta-Brownsville series, which are deep, well-drained soils formed in residuum and colluvium derived from siltstone and fine-grained sandstone. Forest cover is typically composed of chestnut oak (Quercus montana Willd.), black oak (Q. velutina Lam.), northern red oak (Q. rubra L.), white oak (Q. alba L.), red maple (Acer rubrum L.), yellow-poplar (Liriodendron tulipifera L.), sassafras (Sassafras albidum (Nutt.) Nees), and blackgum (Nyssa sylvatica Marsh.), with an abundance of greenbrier (Smilax spp.) and grape vines (Vitis spp.).

Approximately 1215 hectares of the state forest was impacted by the wildfire in 2009, and burn intensities were determined immediately after the fire by a helicopter fly-over of the area based on the amount of canopy leaf destruction. The highest-intensity burn areas experienced $100 \%$ mortality, and a salvage clear-cut harvest was used to remove dead trees during the summer of 2009. 
Paulownia specimens for this study were first located in the burned areas off of hiking trails, logging trails, and dozer lines both in the burned and unburned areas. Each located specimen was tagged, and its GPS location saved and logged for future reference. Paulownia specimens in unburned areas were located along the outer boundaries of the burned area to try to ensure similar soil, topographic, geologic, and moisture characteristics for proper comparison between burned and unburned areas. Of the more than 200 paulownia specimens that were located in both the burned and unburned areas, a total of 61 specimens were randomly selected -28 and 33 specimens in the burned and unburned areas, respectively. Each of the randomly selected paulownia stems served as the plot center, and the minimum possible density of paulownia within a plot was one stem.

Plots without paulownia trees were established and paired with the plots containing paulownia trees within $75 \mathrm{~m}$ of the paulownia plots in the respective burned and unburned areas, having similar slope steepness, aspect, elevation, and soil type as the paired paulownia plot. The 61 plots containing paulownia trees and the corresponding paired plots without paulownia trees provided a total of 122 sample plots. Accordingly, three treatments were evaluated: fire and paulownia present (F-P), fire and no paulownia present (F-NP), and no fire and paulownia present (NF-P). Plots established in unburned areas with no paulownia present (NF-NP) served as a control.

Sample plots were $10 \times 4 \mathrm{~m}$ in size and were divided into $5 \times 2 \mathrm{~m}$ quadrants to facilitate measurements. Within each plot, the total height (to the nearest $1 \mathrm{~cm}$ ) of each paulownia stem was recorded with the use of a telescoping height pole. Paulownia stems that split below $137 \mathrm{~cm}$ height were counted as multiple stems. Canopy closure was measured at the center of each plot with the use of a densiometer.

For this study four important native species or species groups were evaluated. These species were red maple, yellow-poplar, the red oak group (Q. marilandica, $Q$. rubra, $Q$. velutina), and the white oak group (Q.alba, Q. montana). The focus of this study was on the early regeneration of these native species, which was defined as all stems less than $137 \mathrm{~cm}$ in height. A count of each species or species group was performed in each quadrant and summed for the total plot. Three seedlings per species or species group were randomly selected from each quadrant, providing 12 stems per species per plot, and the total height to the nearest $1 \mathrm{~cm}$ was measured and recorded. The recorded heights from each quadrant were combined to determine an average height for the plot by species or species groups.

\subsection{Analysis of Stem Density Data}

The number of regenerating stems and paulownia stems on a plot represents discrete count data that is not normally distributed. Thus, a Poisson model of treatments as the independent variable and stems per hectare as the dependent variable was first used to examine its fit to the data, and the resulting Akaike Information Criterion (AIC) and the overdispersion coefficient were both very high $(4,360,386$ and 12,166.80, respectively). Subsequently a form of the negative binomial model was fitted to the data, producing a much lower AIC (7186.15) and overdispersion coefficient (0.42), and was thus chosen to analyze the stem density data. In the case of the paulownia stems per hectare, the negative binomial model was used with the effect of fire (fire/no fire). In the case for the stems per hectare of native species, the main effects of the model-species, fire (fire/no fire), paulownia (presence/absence) - and their interactions, were initially tested for the total dataset. Subsequently, the same model was run by species, minus the effect of species. Finally, a negative binomial model was used to determine the effects of the three treatments and control on the number of regenerating stems per hectare for native species. A test of the least square means for each treatment individually compared to the control was conducted to determine the level of significance of the difference of each treatment; a Bonferroni correction was applied to each $p$-value. 


\subsection{Analysis of Height Data}

ANOVA was conducted on tree height data for paulownia and native species using a General Linear Model due to the unbalanced nature of the data. The models examined the effects of fire (fire/no fire) as an effect on paulownia tree height, and a mixed model for the total data set of native species that examined the effects of species, fire (fire/no fire), paulownia (presence/absence), and their interactions on the average height of the regenerating native tree species. The mixed model was then used to analyze the height of native species by species, minus the effects of species and corresponding interactions. Analysis of variance was then conducted to determine the effects of the three treatments and control on the average height of the native species. Duncan's multiple range test $(p=0.05)$ was used to compare treatment means, and a Bonferroni correction was applied to each $p$-value.

\section{Results}

\subsection{Fire Effects on Paulownia}

The effects of fire/no fire on paulownia were first tested with a negative binomial model to determine the effects of fire on paulownia stem density. The burned areas displayed a slightly higher and non-significant number of paulownia stems compared to the unburned areas (Table 1). However, the average height of paulownia stems was significantly lower in the burned areas compared to the unburned areas. Although fire did not result in significant change in the number of stems per hectare, the heights of paulownia stems were significantly shorter in the burn areas two years after the wildfire.

Table 1. Analysis of the mean ${ }^{1}$ number of paulownia (Paulownia tomentosa) stems per hectare and the average height in the burned and unburned areas of the 2009 wildfire in Shawnee State Forest, Ohio.

\begin{tabular}{cccccc}
\hline Attribute & Effects & Mean & Std Error & F Value & Prob > F \\
\hline \multirow{2}{*}{ Stems per hectare } & Fire & $648.44 \mathrm{~A}$ & 38.4414 & 2.31 & 0.1297 \\
& No Fire & $568.96 \mathrm{~A}$ & 35.4401 & & \\
\hline \multirow{2}{*}{ Average height $(\mathrm{cm})$} & Fire & $223.15 \mathrm{~A}$ & 15.4134 & 105.73 & $<0.0001$ \\
& No Fire & $797.11 \mathrm{~B}$ & 56.1248 & & \\
\hline
\end{tabular}

${ }^{1}$ Means followed by the same letter are not significantly different within tree attribute, Duncan's MRT, $p=0.05$.

\subsection{Fire and Paulownia Effects on the Number of Regenerating Stems}

The total stem count data was run through the negative binomial model to test for the significance of effects and their interactions (Table 2). The results indicated that species, paulownia (presence/absence), and the interaction of species with fire (fire/no fire) contributed significantly $(p<0.05)$ to the model. The effect of fire was on the threshold of significance $(p=0.540)$, whereas all other effect interactions were not significant.

Table 2. The negative binomial model statistics for the main effects of species, fire (fire/no fire), paulownia (presence/absence) and their interactions to predict the number of stems per hectare for all native species studied combined.

\begin{tabular}{ccccc}
\hline Model Effects & Num DF & Den DF & F Value & Pr $>$ F \\
\hline Species & 3 & 472 & 29.62 & $<0.0001$ \\
Fire & 1 & 472 & 3.73 & 0.0540 \\
Paulownia & 1 & 472 & 6.05 & 0.0143 \\
Fire X Paulownia & 1 & 472 & 0.08 & 0.7814 \\
Species X Fire & 3 & 472 & 6.62 & 0.0002 \\
Species X Paulownia & 3 & 472 & 0.38 & 0.7705 \\
Species X Fire X Paulownia & 3 & 472 & 0.78 & 0.5031 \\
\hline
\end{tabular}

The negative binomial model was run by species with the treatment effects of fire (fire/no fire), paulownia (presence/absence), and their interactions (Table 3). It was found 
was that the fire effect was significant $(p<0.05)$ for all species except red oak. The effect of paulownia was not significant to the model for all species. However, this effect would be significant $(p=0.0741)$ for red oak if the desired confidence level was reduced to $10 \%$. The interactions of these treatment effects were not significant for all species.

Table 3. The negative binomial model statistics for the main effects of fire (fire/no fire), paulownia (presence/absence), and their interactions to predict the number of stems per hectare by species.

\begin{tabular}{cccccc}
\hline Species & Treatment Effects & Num DF & Den DF & F Value & Pr $>$ F \\
\hline \multirow{3}{*}{ Red oak } & Fire & 1 & 118 & 0.13 & 0.7150 \\
& Paulownia & 1 & 118 & 3.25 & 0.0741 \\
& Fire X Paulownia & 1 & 118 & 0.32 & 0.5745 \\
\hline \multirow{3}{*}{ White oak } & Fire & 1 & 118 & 9.58 & 0.0025 \\
& Paulownia & 1 & 118 & 1.42 & 0.2355 \\
& Fire X Paulownia & 1 & 118 & 1.28 & 0.2600 \\
\hline \multirow{3}{*}{ Red maple } & Fire & 1 & 118 & 5.53 & 0.0204 \\
& Paulownia & 1 & 118 & 0.9 & 0.3439 \\
& Fire X Paulownia & 1 & 118 & 0.19 & 0.6650 \\
\hline \multirow{3}{*}{ Yellow-poplar } & Fire & 1 & 118 & 7.97 & 0.0056 \\
& Paulownia & 1 & 118 & 0.64 & 0.4249 \\
& Fire X Paulownia & 1 & 118 & 0.06 & 0.8131 \\
\hline
\end{tabular}

The fact that the effect of paulownia was not significant, and that there were no effect interactions, may suggest that any effect of the presence of paulownia on stem numbers may be additive to the effects of fire. The least square means of stem density were analyzed and plotted by treatment along with the standard errors (Figure 1). Fire alone (treatment F-NP) caused a slight $(10 \%)$ insignificant $(p=0.8794)$ increase in the number of regenerating stems of red oak two years after the fire compared to the control (NF-NP, Figure 1). However, the presence of paulownia in the burn area (treatment F-P) reduced the number of regenerating red oak stems by $64 \%$ but was non-significant $(p=0.1779)$. Outside of the burn area and where paulownia is present (treatment NF-P), the number of regenerating red oak stems was non-significantly $(p=0.3869)$ reduced by $44 \%$ compared to the control.

On plots that experienced fire and no paulownia was present (F-NP), the number of regenerating white oak stems were significantly $(p=0.0012)$ reduced by $88 \%$ compared to the control (NF-NP, Figure 1). The presence of paulownia in the burn areas (F-P) further reduced this number significantly $(p=0.0031)$ by $89 \%$ compared to the control. However, there was no significant difference between the two burn treatments (F-NP and F-P). Outside of the burn area, the presence of paulownia (NF-P) reduced the number of regenerating white oak stems by $69 \%$ compared to the control but was not significant $(p=0.1180)$.

Fire alone (F-NP) did not significantly $(p=0.1686)$ reduce the number of regenerating red maple stems compared to the control (Figure 1). However, the presence of paulownia in the burn area (F-P) significantly $(p=0.0328)$ reduced this number further. The presence of paulownia outside of the burn area (NF-P) reduced the number of regenerating red maple stems but not by a significant $(p=0.7294)$ amount compared to the control.

Fire alone (F-NP) increased the number of regenerating yellow-poplar stems compared to the control (NF-NP) but not significantly $(p=0.1145)$. The presence of paulownia in the burned areas (F-P) reduced this positive response to fire. In the absence of fire, the presence of paulownia (NF-P) reduced the number of regenerating yellow-poplar stems but not by a significant amount $(p=0.6296)$ compared to the control (NF-NP). 


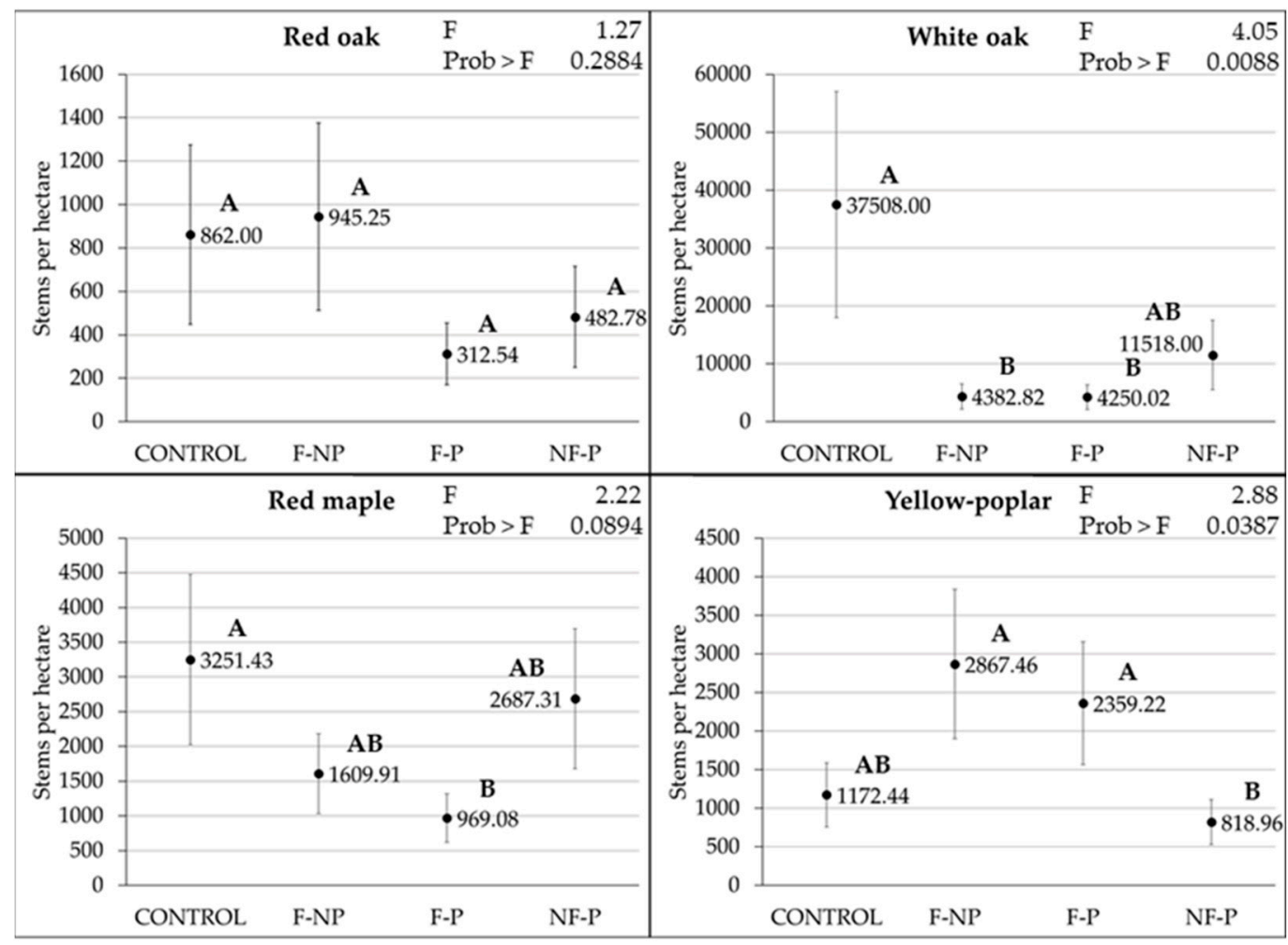

Figure 1. Plots of the least square means with standard errors showing the effects of wildfire and the invasive paulownia (Paulownia tomentosa) species on the number of regenerating stems $(<137 \mathrm{~cm}$ height) per hectare for red and white oaks (Quercus sp.), red maple (Acer rubrum), and yellow-poplar (Liriodendron tulipifera). Mean values are displayed and means with the same capital letters $(\mathrm{A}, \mathrm{B}, \mathrm{C}, \mathrm{D})$ are not significantly $(p=0.05)$ different between treatments within each species. The treatments include fire with no paulownia present (F-NP), fire with paulownia present (F-P), and no fire and paulownia present (NF-P). The treatment no fire and no paulownia present (NF-NP) serves as the control.

When comparing the F-NP treatment with the control (NF-NP), fire significantly reduced the number of regenerating white oak and red maple stems by $88 \%$ and $50 \%$, respectively (Figure 2). Two years after the wildfire, the number of regenerating red oak stems increased only slightly, by $10 \%$. However, yellow-poplar benefited from conditions produced by wildfire two years later with an increase of $145 \%$.

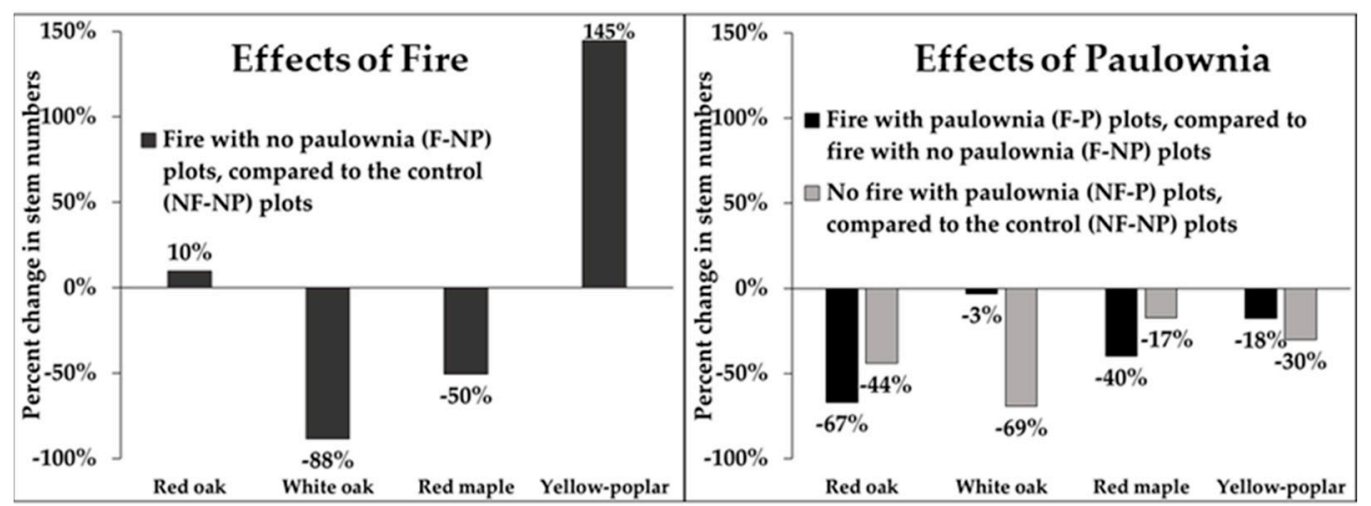

Figure 2. The effects of fire and the presence of paulownia (Paulownia tomentosa) two years after wildfire on the percent change in the number of regenerating stems $(<137 \mathrm{~cm}$ height) of red and white oaks (Quercus sp.), red maple (Acer rubrum), and yellow-poplar (Liriodendron tulipifera).

To examine the effects of paulownia on regenerating stems of the native species, the fire with paulownia (F-P) plots were compared to fire with no paulownia (F-NP) plots, and 
no fire with paulownia (NF-P) plots were compared to the control (NF-NP) plots (Figure 2). In all cases, regardless of whether fire had occurred or not, the number of regenerating stems of the native species studied were reduced when paulownia was present on the plot.

\subsection{Fire and Paulownia Effects on Average Height of Regenerating Stems}

A three-way ANOVA and their interactions was first performed on the entire average height data set of native species using the General Linear Model due to unbalanced data (Table 4). The results indicated that species, fire/no fire, and the interactions of species with fire/no fire and species with presence/absence of paulownia were significant $(p=0.05)$ in explaining the differences in average height.

Table 4. Statistics of the three-way ANOVA examining the effects of species, fire (fire/no fire), paulownia (presence/absence), and their interactions performed on all the height $(<137 \mathrm{~cm})$ data of all native species combined.

\begin{tabular}{ccccc}
\hline Source & Type I SS & Mean Square & F Value & Pr $>$ F \\
\hline Species & $24,637.89$ & 8212.63 & 12.83 & $<0.0001$ \\
Fire & $29,743.34$ & $29,743.34$ & 46.46 & $<0.0001$ \\
Paulownia & 518.89 & 518.89 & 0.81 & 0.3686 \\
Fire X Paulownia & 245.39 & 245.39 & 0.38 & 0.5363 \\
Species X Fire & 9586.54 & 3195.51 & 4.99 & 0.0021 \\
Species X Paulownia & 5523.53 & 1841.18 & 2.88 & 0.0363 \\
Species X Fire X Paulownia & 2159.05 & 719.68 & 1.12 & 0.3394 \\
\hline
\end{tabular}

This analysis was followed by the use of a two-way ANOVA by species to determine effect significance within species (Table 5). With the exception of yellow-poplar, the effect of fire/no fire was highly significant in predicting the average height of regenerating stems. The effect of presence/absence of paulownia and its interaction with fire/no fire was not significant for all species.

Table 5. Statistics of the two-way ANOVA examining the effects of fire (fire/no fire), paulownia (presence/absence), and their interactions by species on the variation of height $(<137 \mathrm{~cm})$ data.

\begin{tabular}{cccccc}
\hline \multirow{2}{*}{ Species } & Source & Type I SS & $\begin{array}{c}\text { Mean } \\
\text { Square }\end{array}$ & F Value & Pr $>$ F \\
& Fire & $16,571.90$ & $16,571.90$ & 19.13 & $<0.0001$ \\
\multirow{2}{*}{ Red oak } & Paulownia & 2221.89 & 2221.89 & 2.57 & 0.1137 \\
& Fire X Paulownia & 54.01 & 54.01 & 0.06 & 0.8035 \\
\hline \multirow{3}{*}{ White oak } & Fire & $10,548.67$ & $10,548.67$ & 37.14 & $<0.0001$ \\
& Paulownia & 156.09 & 156.09 & 0.55 & 0.4608 \\
& Fire X Paulownia & 383.03 & 383.03 & 1.35 & 0.2493 \\
\hline \multirow{2}{*}{ Red maple } & Fire & $12,408.71$ & $12,408.71$ & 19.51 & $<0.0001$ \\
& Paulownia & 1221.87 & 1221.87 & 1.92 & 0.1693 \\
& Fire X Paulownia & 1517.28 & 1517.28 & 2.39 & 0.1261 \\
\hline \multirow{3}{*}{ Yellow-poplar } & Fire & 18.01 & 18.01 & 0.02 & 0.8782 \\
& Paulownia & 2216.20 & 2216.20 & 2.91 & 0.0919 \\
& Fire X Paulownia & 459.07 & 459.07 & 0.60 & 0.4400 \\
\hline
\end{tabular}

Fire alone (F-NP) significantly increased the average height of red oak $(p=0.0095)$, white oak $(p<0.0001)$, and red maple seedlings $(p<0.0001)$ (Figure 3$)$. The presence of paulownia following fire slightly reduced this increased height growth for these species, where the height was still significantly greater for white oak $(p<0.0001)$ and red maple ( $p=0.0396)$ compared to the control. In the absence of fire, the presence of paulownia had no significant impact on average height of all species. With the exception of red oak, all species experienced a slight increase in height growth. No significant changes were detected 
in the average height growth of yellow-poplar across all treatments when compared to the control. The average height growth of yellow-poplar appears to be essentially unaffected by fire and/or the presence of paulownia.

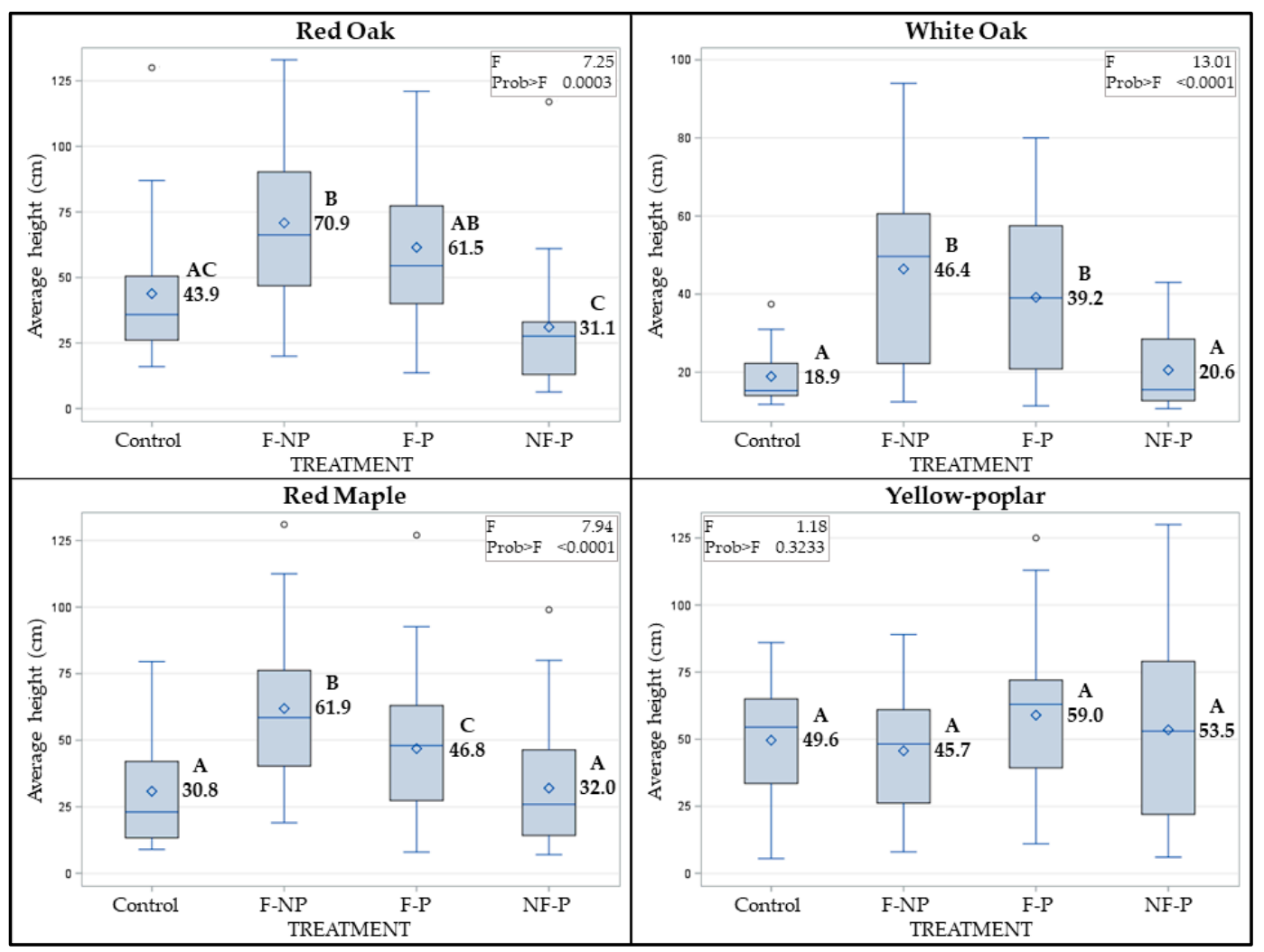

Figure 3. Box plots with mean values displayed showing the effects of wildfire and the invasive paulownia (Paulownia tomentosa) species on the average height of regenerating stems $(<137 \mathrm{~cm}$ height) per hectare for red and white oaks (Quercus sp.), red maple (Acer rubrum), and yellow-poplar (Liriodendron tulipifera). Means with the same letters (A, B, C) are not significantly different $(p=0.05)$ between treatments within each species. The treatments include fire with no paulownia present (F-NP), fire with paulownia present (F-P), and no fire and paulownia present (NF-P). The treatment no fire and no paulownia present (NF-NP) serves as the control.

When comparing the F-NP treatment with the control (NF-NP), fire significantly increased the height of regenerating red oak, white oak, and red maple stems by $61 \%$, $146 \%$, and $101 \%$, respectively (Figure 4). However, yellow-poplar did not benefit in height growth two years after the wildfire, because there was an insignificant $8 \%$ reduction in the average heights of regenerating stems.

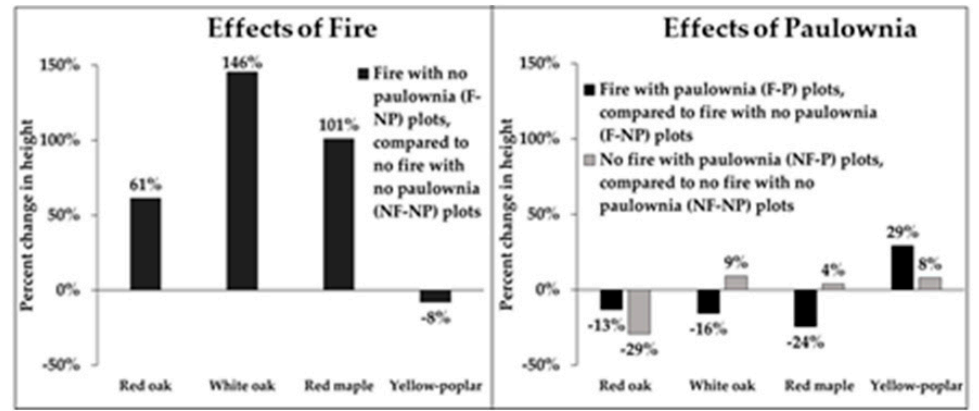

Figure 4. The effects of fire and the presence of paulownia (Paulownia tomentosa) two years after wildfire on the percent change in the average height of regenerating stems $(<137 \mathrm{~cm}$ height) of red and white oaks (Quercus sp.), red maple (Acer rubrum), and yellow-poplar (Liriodendron tulipifera). 
To examine the effects of paulownia's presence on height growth, the fire with paulownia (F-P) plots were compared to fire with no paulownia (F-NP) plots (Figure 4). The average height of the regenerating stems of red oak and white oak were insignificantly reduced by $13 \%$ and $16 \%$, respectively. However, red maple displayed a significant reduction of $24 \%$. Although the height growth of yellow-poplar increased by $29 \%$ in the presence of paulownia following fire, this increase was found to be insignificant due to the high variability in the data.

In the absence of fire, the heights of regenerating stems on the no fire with paulownia (NF-P) plots were compared to the no fire and no paulownia (NF-NP) plots (Figure 4). White oak, red maple, and yellow-poplar displayed insignificant increases of $9 \%, 4 \%$ and $8 \%$, respectively. Red oak was the only species that displayed a decrease in height in the presence of paulownia and the absence of fire. Although red oak displayed a $29 \%$ decrease in the presence of paulownia and absence of fire, this decrease was found to be insignificant.

\section{Discussion}

The 2009 wildfire did not result in a significant increase in the number of paulownia stems compared to areas not affected by the fire. However, areas not affected by the wildfire contained taller paulownia stems. Although the age of paulownia stems was not recorded, this significant taller height difference in the unburned area is likely a reflection of older paulownia stems that were present before the wildfire occurred and not affected by the fire. Paulownia is not considered to be a fire-resistant species, and most fires will top-kill the stems [31]. During a fire, the brittle, hollow branches and large leaves easily burn and contribute to the amount of fuel within a forest [20,31]. Top-killed stems will produce root sprouts because root systems are considered to be insulated from heat damage, even in high severity fires [31]. Post-fire conditions of cleared soils and higher light conditions provide excellent conditions for colonization of paulownia by seed or sprouts $[11,21,23]$. The concern with paulownia is that studies have recorded paulownia juvenile stems growing about $1 \mathrm{~m}$ per year and sprouts more than $5 \mathrm{~m}$, and the leaf area of its large leaves can successfully shade out any undergrowth, including of native species [22]. Thus, the potential exists for this invasive species to dominate and negatively impact native species regeneration.

Two years after wildfire there was not a significantly greater number of paulownia stems in the burn area, although $14 \%$ more stems were found. Whether the number of paulownia stems will continue to increase to significantly more numbers can only be known by revisiting the study area some years later. Paulownia has been found to rapidly invade areas after wildfire and prescribed burns in the Appalachians [21,23]. It is likely that any future increase in stem numbers following fire will be the result of seed dispersal from mature (seed-bearing) trees that exist in the undisturbed portions of the forest, and from mature sprouts that produce seed in the burn areas. Because paulownia seeds are small and delicate, any seed that existed on top of and buried in the soil prior to the fire would likely not have survived [19]. Paulownia is a disturbance-dependent species [20], and seeds into areas and becomes established where disturbances have produced bare mineral soil and abundant sunlight [32].

Red maple and oak species have been shown to benefit from the effects of fire and sunlight availability due to harvesting [33-40]. Although the number of red maple and white oak group seedlings was significantly lower in the fire only (F-NP) areas and the number of red oak group seedlings showed no significant change, heights of all three species were significantly taller in the fire areas than in the non-fire areas. The taller heights are likely due to a much-reduced canopy cover in the areas that experienced fire and subsequent harvests. Fire intensity was highly variable across the study landscape, and two years after fire the average canopy closure in the burned areas was $21 \%$, with a range of $0-90 \%$. This compares to an average canopy closure of $81 \%$ in the unburned areas (range $16-100 \%)$. Pre-burn conditions and fire intensity will play a major role in determining the 
regeneration outcome of particular species [41], and low intensity fires have been shown to be insufficient to stimulate advanced oak regeneration [42,43].

The 2009 wildfire occurred in the spring, and fires that occur in the spring appear to be more detrimental to the establishment of oak and red maple seedlings than fires that occur in the fall $[40,44,45]$. Spring and summer fires have been found to reduce densities of red maple more than fall or winter fires [46]. However, the reports of the effects of fire on red maple have been variable, with some reporting reduced densities $[47,48]$, whereas others report increased densities [40,49]. The time of year at which a fire occurs plays an important role in the response of seedlings to fire. Rootstocks of seedlings contain higher carbohydrate reserves compared to diminished reserves during fires that occur in the spring $[46,50,51]$. In addition, cell activity, including that of the cambium, has diminished or become dormant by late fall. This combination allows seedlings to better withstand fall fires and respond more positively to growth in the spring [52]. Conversely, in the spring, the carbohydrate reserves have begun to migrate out of the rootstocks and cells become more active, making seedlings more vulnerable [50,53-58]. Rootstocks are also more likely to survive fire when seedlings are dormant [59].

Yellow-poplar was the only species that displayed a significant positive response to fire. Fire enhances the regeneration of yellow-poplar by releasing seed that has been stored on the forest floor [60,61]. Yellow-poplar seeds are generally resistant to heat damage [62], need overwintering to break dormancy [61], and can remain viable in the forest floor from 4-7 years [63]. Fires, which put seeds in contact with mineral soil, can significantly increase the number of seedlings established $[49,64]$. Therefore, the timing of seed placement on the forest floor in regard to timing of fire is important. One study [49] found that after an early spring (April) fire the number of new yellow-poplar seedlings was significantly higher than that in unburned areas. The stimulation of seed by fire and the exposure of seed to nutrient-rich mineral soil immediately prior to germination are important factors relating to the timing of fire.

There also were no significant differences in yellow-poplar height growth across all treatments compared to the control. Yellow-poplar has a more competitive strategy in resource allocation which allows its rapid height growth [65]. This basically is a strategy of rapid stem development over root growth [66]. When light is not limiting, such as in more open canopies following fire, faster-growing yellow-poplar will often out-compete oak and other species, particularly on higher-quality sites [67]. These more open canopies, plus the reduced forest litter, enables rapid germination and establishment of these fast-growing seedlings [68].

Although the effects of paulownia and its interaction with fire displayed no significance in the models, there still appears to be a negative impact on the number of regenerating stems for all species regardless of whether plots were burned. In the plots that experienced fire, the presence of paulownia reduced the number of regenerating stems for red oak, white oak, red maple, and yellow-poplar by $67 \%, 3 \%, 40 \%$, and $18 \%$, respectively, compared to plots that only experienced fire. For the plots that did not experience fire, the presence of paulownia reduced the number of stems per hectare for red oak, white oak, red maple, and yellow-poplar by $44 \%, 69 \%, 17 \%$, and $30 \%$, respectively, compared to the control. Invasive species can indirectly affect native plants by changing habitat conditions and ecological processes, or directly by competing with native species for resources and space [69]. One study [27] found that fire promotes the invasion of paulownia but is not necessary for subsequent recruitment, and its presence reduces the native plant diversity.

In many cases, invasive non-native plants have an advantage over native species, which leads to reduced biodiversity of an area and monopolizes resources in its introduced habitat $[70,71]$. These non-native plants are able to out-compete native plants because they have evolved advantageous adaptations in their natural habitat or exhibit greater plasticity, allowing them to thrive in new ecosystems [72,73]. Invasive non-native species can also indirectly affect native plants by changing habitat conditions and ecological processes, or directly by competing with native species for resources and space [69]. In these ways, 
non-native species can have a negative effect on the vegetation composition, which can lead to a decrease in biodiversity. As species richness declines, ecosystems are considered to be more susceptible to invasions, thus perpetuating a cycle of reduced biodiversity [16,19].

Although all species displayed increased height growth in the burned areas, the presence of paulownia in these areas reduced this response for white oak, red oak, and red maple. Within these areas it is likely that the large leaves of paulownia produced enough shading to affect the height growth of these species, whereas the rapid growth of yellow-poplar enabled this species to compete effectively. Leaves reaching one meter in length and width are reported for paulownia, with larger sizes on saplings and root sprouts [12,20,74]. Paulownia's shade intolerance, rapid growth, and persistent early successional status would result in the growth and expansion of paulownia foliage in these post-fire conditions [19]. Where paulownia was present in the unburned areas, there was no significant impact on height growth, possibly due to a more closed canopy and the occurrence of previously established understory vegetation.

Invasive species will always be a threat to ecosystems, and removing them from systems and preventing conditions that facilitate their spread and establishment is important for future management. For paulownia, due to its high numbers of wind-dispersed seeds, an affinity for full light, and a tolerance to dry conditions, this includes cleared areas in forests [31]. Some fires are not preventable, some fires are necessary, and logging is often a necessary part of management. Preventing conditions that are necessary for the establishment and spread of paulownia will not always be possible. Therefore, it is critical to remove paulownia seed sources (seed-bearing trees) that exist within the forest before these conducive conditions occur.

\section{Conclusions}

Paulownia invaded areas that had experienced the wildfire. Although the number of paulownia stems was slightly greater than that in the unburned areas, the difference was not significant. Accordingly, paulownia took advantage of the post-fire conditions to be-come established, but not in dominating numbers.

The responses of the native species studied two years after wildfire were mixed, as the number of regenerating stems of white oak and red maple were significantly reduced, whereas the number of red oak stems increased slightly, and the number of yellow-poplar stems increased significantly. In areas in which paulownia occurred and experienced wildfire, all species displayed a reduction in the number of regenerating stems compared to paulownia's absence in the burn areas. Where paulownia occurred in areas not affected by the wildfire, all the native species studied displayed a reduction in the number of regenerating stems.

The average heights of red oak, white oak, and red maple were significantly taller when growing in areas affected by the wildfire due to a more open canopy. However, there was no significant change in the average heights of yellow-poplar. The presence of paulownia in the unburned areas did not significantly impact the height growth of the native species studied.

This research provides a snapshot of the effects of fire and paulownia two years after the wildfire on the regenerating stems of red oak, white oak, red maple, and yellow-poplar. Whether these effects will continue to the same degree in the future can only be determined with a re-inventory of the wildfire area some years later.

There are some limitations to this study because post-fire salvage logging occurred on some of the burn plots that experienced high intensity fire. However, we believe that logging had a minimal impact on the reduction of the canopy cover, which occurred on all burn plots regardless of logging. One other factor not accounted for was the soil disturbance that may have occurred as the result of logging on the burn plots. Although post-fire logging did not occur on all burn plots, any resulting soil disturbance could be a confounding variable to this study. 
Author Contributions: Conceptualization, R.W.; methodology, R.W.; validation, R.W. and H.W.; formal analysis, R.W. and H.W.; investigation, R.W. and H.W.; resources, R.W.; data curation, R.W. and H.W.; writing — original draft preparation, R.W. and H.W.; writing-review and editing, R.W.; visualization, R.W.; supervision, R.W.; project administration, R.W.; funding acquisition, R.W. All authors have read and agreed to the published version of the manuscript.

Funding: This research was funded by the McIntire-Stennis Act of 1962 (P.L. 87-788), project number OHO00053-MS.

Institutional Review Board Statement: Not applicable.

Informed Consent Statement: Not applicable.

Data Availability Statement: The data presented in this study are openly available in DRYAD at https: / / doi.org/10.5061/dryad.3bk3j9kkj.

Acknowledgments: The authors would like to acknowledge Angela Chongpinitchai and Alina Neel for their invaluable assistance in collecting the field data for this study.

Conflicts of Interest: The authors declare no conflict of interest.

\section{References}

1. Clewley, G.D.; Eschen, R.; Shaw, R.H.; Wright, D.J. The effectiveness of classical biological control of invasive plants. J. Appl. Ecol. 2012, 49, 1287-1295. [CrossRef]

2. Mack, R.N.; Simberloff, D.; Lonsdale, W.M.; Evans, H.; Clout, M.; Bazzaz, F.A. Biotic invasions: Causes, epidemiology, global consequences, and control. Ecol. Appl. 2000, 10, 689-710. [CrossRef]

3. Vitousek, P.M.; Dantonio, C.M.; Loope, L.L.; Rejmanek, M.; Westbrooks, R. Introduced species: A significant component of human-caused global change. New Zeal. J. Ecol. 1997, 21, 1-16. Available online: https://www.jstor.org/stable/24054520 (accessed on 6 August 2021).

4. Vila, M.; Espinar, J.L.; Hejda, M.; Hulme, P.E.; Jarosik, V.; Maron, J.L.; Pergl, J.; Schaffner, U.; Sun, Y.; Pysek, P. Ecological impacts of invasive alien plants: A meta-analysis of their effects on species, communities and ecosystems. Ecol. Lett. 2011, 14, 702-708. [CrossRef]

5. Bezemer, T.M.; Harvey, J.A.; Cronin, J.T. Response of native insect communities to invasive plants. Annu. Rev. Entomol. 2014, 59, 119-141. [CrossRef] [PubMed]

6. Blossey, B. Before, during and after: The need for long-term monitoring in invasive plant species management. Biol. Invasions 1999, 1, 301-311. [CrossRef]

7. Zedler, J.B.; Kercher, S. Causes and consequences of invasive plants in wetlands: Opportunities, opportunists, and out-comes. Crit. Rev. Plant Sci. 2004, 23, 431-452. [CrossRef]

8. Crawley, M.J.; Harvey, P.H.; Purvis, A. Comparative ecology of the native and alien floras of the British Isles. Philos. Trans. R. Soc. Lond. Ser. B Biol. Sci. 1996, 351, 1251-1259. [CrossRef]

9. Pimentel, D.; Zuniga, R.; Morrison, D. Update on the environmental and economic costs associated with alien-invasive species in the United States. Ecol. Econ. 2005, 52, 273-288. [CrossRef]

10. Essl, F. From ornamental to detrimental? The incipient invasion of Central Europe by Paulownia tomentosa. Preslia 2007, 79, 377-389.

11. Tang, R.C.; Carpenter, S.B.; Wittwer, R.F.; Graves, D.H. Paulownia-A crop tree for wood products and reclamation of surfacemined land. South J. Appl. For. 1980, 4, 19-24. [CrossRef]

12. Preston, D. Paulownia: A miracle tree or passing fancy? Am. For. 1983, 89, 15-19, 47-52.

13. Rejmanek, M.; Richardson, D.M. What attributes make some plant species more invasive? Ecology 1996, 77, 1655-1661. [CrossRef]

14. Goodwin, B.J.; McAllister, A.J.; Fahrig, L. Predicting invasiveness of plant species based on biological information. Conserv. Biol. 1999, 13, 422-426. [CrossRef]

15. Herron, P.M.; Martine, C.T.; Latimer, A.M.; Leicht-Young, S.A. Invasive plants and their ecological strategies: Prediction and explanation of woody plant invasion in New England. Divers. Distrib. 2007, 13, 633-644. [CrossRef]

16. Martin, P.H.; Canham, C.D.; Marks, P.L. Why forests appear resistant to exotic plant invasions: Intentional introductions, stand dynamics, and the role of shade tolerance. Front Ecol. Environ. 2009, 7, 142-149. [CrossRef]

17. Millsaps, V. The structure and development of the seed Paulownia tomentosa. J. Elisha Mitch. Sci. Soc. 1936, 52, 56-75.

18. Carpenter, S.B.; Immel, M.J.; Smith, N.D. Effect of photoperiod on the growth and photosynthetic capacity of Paulownia seedlings. Castanea 1983, 48, 13-18.

19. Kuppinger, D.M. Post-Fire Vegetation Dynamics and the Invasion of Paulownia tomentosa in the Southern Appalachians. Ph.D. Thesis, Univ. of North Carolina at Chapel Hill, Chapel Hill, NC, USA, 2008.

20. Hu, S.Y. The economic botany of the Paulownias. Econ. Bot. 1961, 15, 11-27. [CrossRef]

21. Langdon, K.R.; Johnson, K.D. Additional notes on invasiveness of Paulownia tomentosa in natural areas. Nat. Area J. 1994, 14, 139-140. 
22. Beckjord, P.R.; McIntosh, M.S. Paulownia tomentosa: Effects of fertilization and coppicing in plantation establishment. South J. Appl. For. 1983, 7, 81-85. [CrossRef]

23. Kuppinger, D.M.; Jenkins, M.A.; White, P.S. Predicting the post-fire establishment and persistence of an invasive tree species across a complex landscape. Biol. Invasions 2010, 12, 3473-3484. [CrossRef]

24. Keeley, J.E. Fire management impacts on invasive plants in the western United States. Conserv. Biol. 2006, 20, 375-384. [CrossRef]

25. Pysek, P.; Jarosik, V.; Hulme, P.E.; Pergl, J.; Hejda, M.; Schaffner, U.; Vila, M. A global assessment of invasive plant impacts on resident species, communities and ecosystems: The interaction of impact measures, invading species' traits and environment. Glob. Chang. Biol. 2012, 18, 1725-1737. [CrossRef]

26. Hagan, D.L.; Waldrop, T.A.; Reilly, M.; Shearman, T.M. Impacts of repeated wildfire on long-unburned plant communities of the southern Appalachian Mountains. Int. J. Wildland Fire 2015, 24, 911-920. [CrossRef]

27. Lovenshimer, J.B.; Madritch, M.D. Plant community effects and genetic diversity of post-fire princess tree (Paulownia tomentosa) invasions. Invasive Plant Sci. Manag. 2017, 10, 125-135. [CrossRef]

28. Sutherland, E.K.; Hutchinson, T.F. Characteristics of Mixed-Oak Forest Ecosystems in Southern Ohio Prior to the Reintroduction of Fire; USDA For. Serv., Gen. Tech. Rep. NE-299; Northeastern Forest Experiment Station: Newtown Square, PA, USA, 2003; 159p.

29. NIFC; Fire Statistics. National Interagency Fire Center, 2021. Available online: https://www.nifc.gov/fire-information/statistics (accessed on 6 August 2021).

30. Chongpinitchai, A.R.; Williams, R.A. The response of the invasive princess tree (Paulownia tomentosa) to wildland fire and other disturbances in an Appalachian hardwood forest. Glob. Ecol. Conserv. 2021, 29, e01734. [CrossRef]

31. Innes, R.J. Paulownia Tomentosa. In: Fire Effects Information System, U.S. Department of Agriculture, Forest Service, Rocky Mountain Research Station, Fire Sciences Laboratory. 2009. Available online: https:/ /www.fs.fed.us/database/feis/plants/tree/ pautom/all.html (accessed on 18 June 2021).

32. Longbrake, A.C.W. Ecology and Invasive Potential of Paulownia tomentosa (Scrophulariaceae) in a Hardwood Forest Landscape. Ph.D. Thesis, Ohio Univ., Athens, OH, USA, 2001.

33. Alexander, H.D.; Arthur, M.A.; Loftis, D.L.; Green, S.R. Survival and growth of upland oak and co-occurring competitor seedlings following single and repeated prescribed fires. For. Ecol. Manag. 2008, 256, 1021-1030. [CrossRef]

34. Fei, S.; Steiner, K.C. Rapid capture of growing space by red maple. Can. J. For. Res. 2009, 39, 1444-1452. [CrossRef]

35. Green, S.R.; Arthur, M.A.; Blankenship, B.A. Oak and red maple seedling survival and growth following periodic pre-scribed fire on xeric ridgetops on the Cumberland Plateau. For. Ecol. Manag. 2010, 259, 2256-2266. [CrossRef]

36. Groninger, J.W.; Long, M.A. Oak ecosystem management considerations for central hardwoods stands arising from silvicultural clearcutting. North J. Appl. For. 2008, 25, 173-179. [CrossRef]

37. Hutnik, R.J.; Yawney, H.W. Red maple (Acer rubrum L.). In Silvics of forest trees of the United States; Handbook 271; Fowells, H.A., Ed.; U.S. Department of Agriculture: Washington, DC, USA, 1965; pp. 57-62.

38. Royse, J.; Arthur, M.A.; Schorgendorfer, A.; Loftis, D.L. Establishment and growth of oak (Quercus alba, Quercus prinus) seedlings in burned and fire-excluded upland forests on the Cumberland Plateau. For. Ecol. Manag. 2010, 260, 502-510. [CrossRef]

39. Schweitzer, C.J.; Dey, D.C. Forest structure, composition, and tree diversity response to a gradient of regeneration harvests in the mid-Cumberland Plateau escarpment region, USA. For. Ecol. Manag. 2010, 262, 1729-1741. [CrossRef]

40. Xin, Y.; Williams, R.A. Effects of burn season on large seedlings of oak and other hardwood regeneration three years after shelterwood harvest. For. Stud. Metsanduslikud Uurim. 2019, 71, 1-16. [CrossRef]

41. Iverson, L.R.; Hutchinson, T.F.; Prasad, A.M.; Peters, M.P. Thinning, fire, and oak regeneration across a heterogeneous landscape in the eastern U.S.: 7-year results. For. Ecol. Manag. 2008, 255, 3035-3050. [CrossRef]

42. Blankenship, B.A.; Arthur, M.A. Stand structure over 9 years in burned and fire-excluded oak stands on the Cumberland Plateau, Kentucky. For. Ecol. Manag. 2006, 225, 134-145. [CrossRef]

43. Hutchinson, T.F.; Sutherland, E.K.; Yaussy, D.A. Effects of repeated prescribed fires on the structure, composition, and regeneration of mixed oak forests in Ohio. For. Ecol. Manag. 2005, 218, 210-228. [CrossRef]

44. Rouse, C. Fire effects in northeastern forests: Oak. In General Technical Report NC-105; U.S. Department of Agriculture, Forest Service, North Central Forest Experiment Station: St. Paul, MN, USA, 1986; 7p.

45. Rundel, P.W. Adaptations of Mediterranean climate oaks to environmental stress. In Proceedings of the Symposium on the Ecology, Management and Utilization of California Oaks. In General Technical Report PSW-44. Berkeley; Department of Agriculture, Forest Service, Pacific Southwest Forest and Range Experiment Station: Claremont, CA, USA, 1980; pp. 43-54.

46. Brose, P.H.; Van Lear, D.H. Responses of hardwood advance regeneration to seasonal prescribed fires in oak-dominated shelterwood stands. Can. J. For. Res. 1998, 28, 331-339. [CrossRef]

47. Reich, P.B.; Abrams, M.D.; Ellsworth, D.S.; Kruger, E.L.; Tabone, T.J. Fire affects ecophysiology and community dynamics of central Wisconsin oak forest regeneration. Ecology 1990, 71, 2179-2190. [CrossRef]

48. Elliott, K.J.; Hendrick, R.L.; Major, A.E.; Vose, J.M.; Swank, W.T. Vegetation dynamics after a prescribed fire in the southern Appalachians. For. Ecol. Manag. 1999, 114, 199-213. [CrossRef]

49. Shearin, A.T.; Bruner, M.H.; Goebel, N.B. Prescribed burning stimulates natural regeneration of yellow-poplar. J. For. 1972, 70, 482-484. [CrossRef]

50. Hodgkin, E.J. Effects of Fire on Undergrowth Vegetation in Upland Southern Pine Forests. Ecology 1958, 39, 36-46. [CrossRef] 
51. Ferguson, E.R. Effects of prescribed fires on understory stems in pine-hardwood stands in east Texas. J. For. 1961, 59, 356-359. [CrossRef]

52. Drewa, P.B.; Platt, W.J.; Moser, E.B. Fire effects on resprouting of shrubs in headwaters of southeastern longleaf pine savannas. Ecology 2002, 83, 755-767. [CrossRef]

53. Langdon, O.G. Some effects of prescribed fire on understory vegetation in loblolly pine stands. In Proceedings, Prescribed Fire and Wildlife in Southern Forests: Wood; Clemson University: Clemson, SC, USA, 1981; pp. 143-153.

54. Garrison, G.A. Carbohydrate reserves and response to use. In Wildland Shrubs-Their Biology and Utilization; McKell, C.M., Blaisdell, J.P., Goodin, J.R., Eds.; U.S. Department of Agriculture, Forest Service, Intermountain Forest and Range Experiment Station: Ogden, UT, USA, 1972; pp. 271-278.

55. Hough, W.A. Carbohydrate reserves of saw-palmetto: Seasonal variation and effects of burning. For. Sci. 1968, 14, 399-405. [CrossRef]

56. Volland, L.A.; Dell, J.D. Fire Effects on Pacific Northwest Forest and Range Vegetation; U.S. Department of Agriculture, Forest Service, Pacific Northwest Region: Portland, OR, USA, 1981; 23p.

57. Bond, W.J.; van Wilgen, B.W. Fire and Plants; Chapman and Hall: London, UK, 1996; 272p.

58. DeBano, L.F.; Neary, D.G.; Ffolliott, P.F. Fire's Effects on Ecosystems; John Wiley \& Sons: New York, NY, USA, 1998; 333p.

59. Cain, M.D.; Shelton, M.G. Survival and growth of Pinus echinata and Quercus seedlings in response to simulated summer and winter prescribed burns. Can. J. For. Res. 2000, 30, 1830-1836. [CrossRef]

60. McNab, W.H.; Berg, E.C.; Oprean, T.M., III. Response to prescribed burning of five year old hardwood regeneration on a mesic site in the southern Appalachian Mountains. In Proceedings of the 15th Biennial Southern Silvicultural Research Conference; U.S. Department of Agriculture, Forest Service, Southern Research Station: Asheville, NC, USA, 2013; pp. 513-517.

61. Beck, D.E. Liriodendron tulipifera L. Yellow-poplar. In Silvics of North America; 2. Hardwoods. U.S.D.A., Agricul. Handb. 654; Burns, R.M., Honkala, B.H., Eds.; USDA Forest Service: Washington, DC, USA, 1990; pp. 406-416.

62. Griffith, R.S. Liriodendron tulipifera. In Fire Effects Information System; U.S. Department of Agriculture, Forest Service, Rocky Mountain Research Station, Fire Sciences Laboratory (Producer): Missoula, MT, USA, 1991. Available online: https://www.fs.fed. us / database/feis/plants/tree/lirtul/all.html (accessed on 6 August 2021).

63. Clark, F.B.; Boyce, S.G. Yellow-poplar seed remains viable in the forest litter. J. For. 1964, 62, 564-567. [CrossRef]

64. Clark, F.B. Measures necessary for natural regeneration of oaks, yellow-poplar, sweetgum, and black walnut. In The Silviculture of Oaks and Associated Species; Research Paper NE-144; USDA Forest Service, Northeastern Forest Experiment Station: Broomall, PA, USA, 1970; pp. 1-16.

65. Brose, P.H.; Van Lear, D.H. Survival of hardwood regeneration during prescribed fires: The importance of root development and root collar location. In General Technical Report SRS-73; USDA Forest Service, Southern Research Station: Asheville, NC, USA, 2004; pp. 123-127.

66. Call, L.J.; Nilsen, E.T. Analysis of spatial patterns and spatial association between the invasive tree-of-heaven (Ailanthus altissima) and the native black locust (Robinia pseudoacacia). Am. Midl. Nat. 2003, 150, 1-14. [CrossRef]

67. McNabb, W.H. A preliminary model of yellow-poplar seedling establishment two years after a growing season pre-scribed fire in southern Appalachian oak stands. In Proceedings of the 18th Biennial Southern Silvicultural Research Conference, Knoxville, TN, USA, 2-5 March 2015; pp. 582-588.

68. Kolb, T.E.; Steiner, K.C.; McCormick, L.H.; Bowersox, T.W. Growth response of northern red oak and yellow-poplar seedlings to light, soil moisture, and nutrients in relation to ecological strategy. For. Ecol. Manag. 1990, 38, 65-78. [CrossRef]

69. Schwartz, M.W.; Heim, J.R. Effects of a prescribed fire on degraded forest vegetation. Nat. Areas J. 1996, 16, $184-191$.

70. Brooks, M.L.; D’Antonio, C.M.; Richardson, D.M.; Grace, J.B.; Keeley, J.E.; DiTomaso, J.M.; Hobbs, R.J.; Pellant, M.; Pyke, D. Effects of invasive alien plants on fire regimes. BioScience 2004, 54, 677-688. [CrossRef]

71. Canham, C.D. Different responses to gaps among shade-tolerant tree species. Ecology 1989, 70, 548-550. [CrossRef]

72. Allendorf, F.W.; Lundquist, L.L. Introduction: Population biology, evolution, and control of invasive species. Conserv. Biol. 2003, 17, 24-30. Available online: https:/ / www.jstor.org/stable/3095269 (accessed on 1 August 2021). [CrossRef]

73. Sakai, A.K.; Allendorf, F.W.; Holt, J.S.; Lodge, D.M.; Molofsky, J.; With, K.A.; Baughman, S.; Cabin, R.J.; Cohen, J.E.; Ellstrand, N.C.; et al. The population biology of invasive species. Annu. Rev. Ecol. Syst. 2001, 32, 305-332. [CrossRef]

74. Rebbeck, J. Fire management and woody invasive plants in oak ecosystems. In Proceedings of the 4th Fire in Eastern Oak Forests Conference, Springfield, MO, USA, 17-19 May 2011; pp. 142-155. 